\title{
Effects of Natural and Anthropogenic Environmental Changes on Riverine Fish Assemblages: a Framework for Ecological Assessment of Rivers
}

\author{
Francisco Leonardo Tejerina-Garro ${ }^{1 *}$, Mabel Maldonado ${ }^{2}$, Carla Ibañez ${ }^{2}$, Didier Pont $^{3}$, \\ Nicolas Roset $^{3}$ and Thierry Oberdorff ${ }^{4}$ \\ ${ }^{1}$ Centro de Biologia Aquática; Campus II; Universidade Católica de Goiás; Av. Bela Vista km 2; Jardim Olímpico; \\ 74605-010; Goiânia - GO - Brazil. ${ }^{2}$ ULRA; Universidad Mayor de San Simon; Facultad de Ciencias y Tecnologia; \\ Casilla de correo 992; Cochabamba - Bolivia. ${ }^{3}$ Laboratoire d'Ecologie des Eaux Douces; ESA-CNRS 5023; \\ Université Lyon I; 43 Bld du 11 Novembre 1918; 69622 Villeurbanne cedex; France. ${ }^{4}$ Institut de Recherche pour le \\ Développement; ULRA; Universidad Mayor de San Simon; Facultad de Ciencias y Tecnologia; Casilla de \\ correo 992; Cochabamba - Bolivia
}

\begin{abstract}
Freshwater is a basic need for the mankind. Effective biological tools (ecologically based, efficient, rapid and consistently applicable to different ecological regions) are needed to measure the "health" of rivers. Adapting such tools over a broad geographic area requires a detailed understanding of both the patterns of organisms assemblage composition and distribution within and among water bodies under natural conditions, and the nature of the major environmental gradients that cause or explain these patterns. A comprehensive review of the available litterature dealing with the identification of environmental factors structuring riverine fish assemblages under natural conditions permits to identify the most consistent ones.
\end{abstract}

Keywords: Biological indices, fish community, environmental parameters, habitat

\section{INTRODUCTION}

Rivers are among the most intensively human influenced ecosystems on the earth. They serve for transportation, water supply and power generation and also as source of food and sinks for waste products. As a result, in highly industrialized countries and in some developing countries, many rivers are now severely polluted. Most common impacts are channel and bank modifications (i.e., canalisation for navigation or agricultural purposes, bank protection), flow regulation and fragmentation (i.e. dams and weirs, reservoirs for water supply, diversion for irrigation and industrial purposes), chemical pollution (e.g. heavy metals, pesticides, fertilizers), and organic pollution (e.g. domestic and cattle-raising waste water). All these alterations have led to an extensive ecological degradation of these rivers making them no longer sustainable in providing goods and services (e.g. decline in water quality and availability, intense flooding, changes in the distribution and structure of aquatic biota) (Poff et al., 1997) (Fig. 1). Recognition of these adverse effects on river systems has driven initiatives for river restoration. Nevertheless, until recently river restoration protocols were contingent upon defined uses,

*Author for correspondence 
which were typically human-oriented (drinking water, fishing, swimming) or extremely ill-defined (aquatic life, fish passage).

This kind of policy proved successful to solve problems related to point source pollution, but was poorly adapted to integrate management of river ecosystems. As a consequence, while the chemical water quality in running waters has been considerably improved, the biological and hydromorphological qualities have continued to deteriorate.

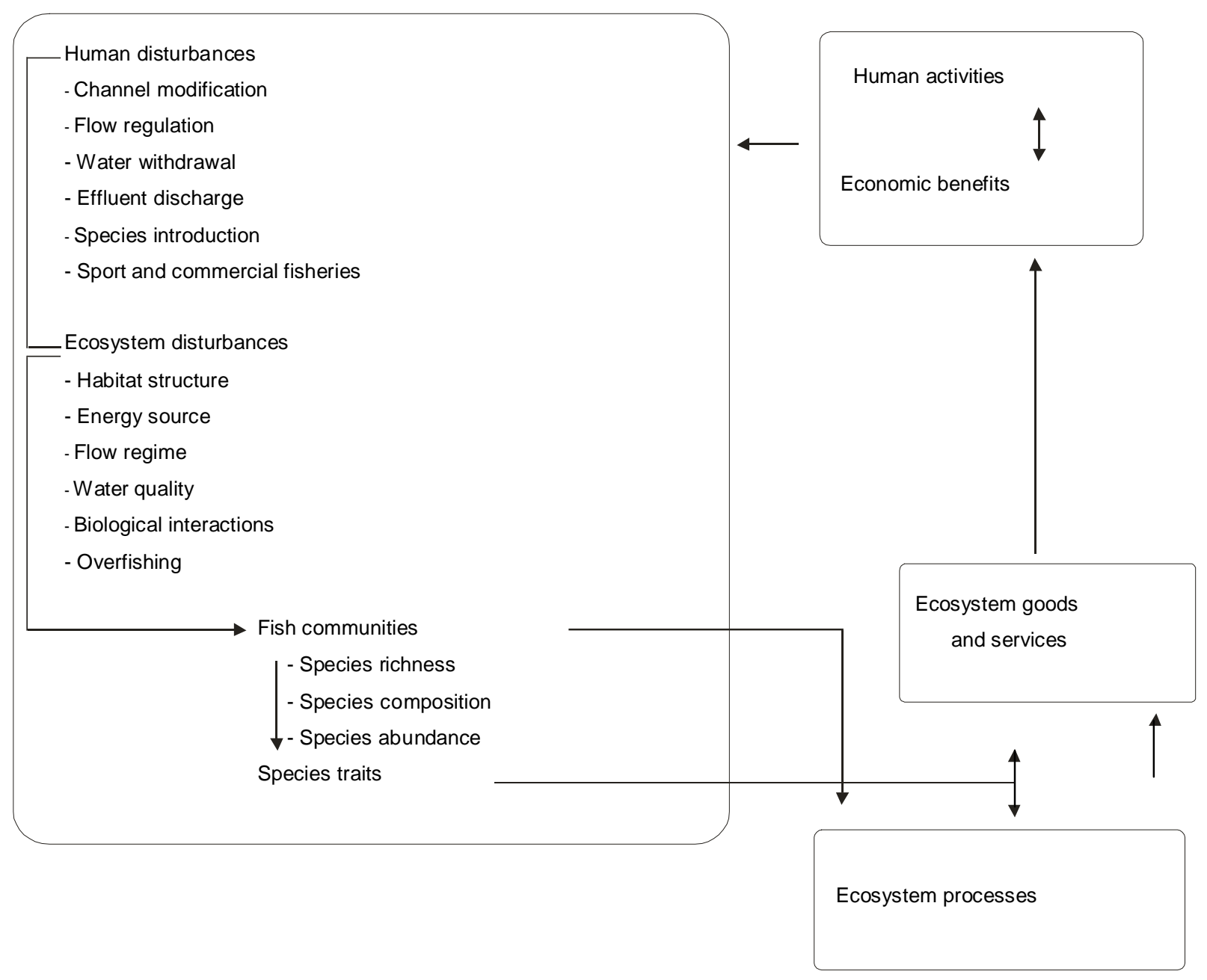

Figure 1 - Relationships between human activities and river ecosystem processes.

Developing countries, like those in South America, and highly industrialized countries, like those in Western Europe, have faced this situation differently. For example, water policy in Brazil continues to concentrate on water pollution even if major river environmental changes are observed due to deforestation, hydroelectric dams, waste water or gold mining (Pringle et al., 2000). In this case measures that attempt to anticipate or predict significant economic, social and ecological impacts rather than react to them, are increasingly necessary for avoiding extreme environmental degradation (Hocutt et al., 1994). The European Community has recently changed its water policy as emphasized by the new European Water Framework Directive (WFD), which requires the restoration and maintenance of "healthy" aquatic ecosystems by the assessment of their hydromorphological, chemical and biological characteristics. Thus, the goal is not only to preserve these ecosystems, but also to rehabilitate them in an attempt to restore their ecological structures, functions, and integrity. Consequently, in both highly industrialized and less developed 
countries, it is necessary to develop practical and effective ecological tools based on biological assemblage for monitoring water resource quality (Hughes and Oberdorff, 1999).

These tools need to be ecologically based, efficient, rapid and consistently applicable to different ecological regions. Nevertheless, effectively adapting such tools over a broad geographic area requires a detailed understanding of both patterns of organisms assemblage composition and distribution within and among water bodies under natural conditions, and the nature of the major environmental gradients that cause, or at least explain, these patterns (Smogor and Angermeier, 1999). This will permit to obtain a response of aquatic biota to human stressors that can be discriminated from natural variation. For aquatic ecosystems, biological indicators can be chosen from many assemblages (i.e. phytoplankton, macrophytes, benthic invertebrate or fish), but fish are of particular interest because 1) they are present in most water bodies, 2) their taxonomy, ecological requirements and life histories are generally better known than those of other assemblages, 3) they occupy a variety of trophic levels and habitats, and 4) they have both economic and aesthetic values and thus help raise awareness of the value of conserving aquatic systems.

This paper proposes to illustrate the elaboration process of such biological tools. To address this issue we will first review the most important findings on the role of environmental factors in influencing local fish assemblages' structure in natural condition. We will limit to particular sets of factors that have been identified as significant in multiple studies and focus on both temperate and tropical fish fauna. We will also describe and evaluate (advantages and disadvantages) the fishbased methods integrating information on assemblage species richness, composition and abundance, and currently available for the assessment of the ecological quality of streams and rivers. Finally, we will give some guidelines for the elaboration of a biological tool based on fish assemblages for better assessment of rivers health across large regions for long time periods.

\section{FACTORS STRUCTURING RIVERINE FISH ASSEMBLAGES IN TEMPERATE AND TROPICAL REGIONS}

Although for many years intrinsic and extrinsic local processes (e.g. competition, predation, disturbance) were the focus of studies seeking to explain local fish assemblage structure (Schlosser, 1995), emphasis on the role of regional processes has increased as some studies have demonstrated their pervasive role in shaping local assemblages (Hughes et al., 1987; Whittier et al., 1988; Hugheny and Paugy, 1995; Hugueny et al., 1997; Belkessam et al., 1997; Angermeier and Winston, 1998; Oberdorff et al., 1998). Consequently, complete answers for the explanation of local fish assemblage richness and structure must address the relative importance of large-scale processes, which determine the species available to occur locally and small-scale processes, which should limit the number of species that actually occur locally (Angermeier and Winston, 1998). The important ecological question to be answered before defining biological tools based on fish assemblages to assess anthropogenic perturbations becomes what is the relative importance of local (biotic and abiotic) and regional factors in determining local assemblages structure and richness? The answer to this question it is crucial for establishing, and possibly regionalizing, suitable biological tools for evaluating the biotic integrity of rivers.

\section{ROLE OF ABIOTIC FACTORS PROCESSES OCCURRING AT THE LOCAL LEVEL}

Longitudinal changes in local assemblage richness and composition have usually been attributed to one of two processes: biotic zonation or continual addition of species downstream. Biotic zonation corresponds to discontinuities in river geomorphology or abiotic conditions promoting distinct assemblages along the longitudinal gradient (Huet, 1959; Schlosser, 1982; Balon et al., 1986; Rahel and Hubert, 1991; Oberdorff et al., 1993; Belliard et al., 1997). For example, species replacement may occur as a result of physiological specialization for temperature (Ferguson, 1958). However, additions of species are usually related to environmental gradients having smooth transitions of abiotic factors 
contributing to nested patterns of assemblage composition along the longitudinal gradient (Sheldon, 1968, Rahel and Hubert, 1991).

Whatever be the process (i.e. biotic zonation or species addition) the local species richness usually increases along the upstream-downstream gradient. The few studies conducted in tropical streams and rivers reveal patterns that generally agree with patterns from temperate regions (e.g. Ibarra and Stewart 1989, Tito de Morais and Lauzanne, 1994; Mazzoni and Lobon-Cervia, 2000). This gradual accumulation of species is often attributed to a downstream increase in habitat size, habitat diversity, or both (e.g. measured as a function of stream width, volume, discharge, order, drainage basin area, depth, current velocity, substrate composition) (Sheldon, 1968; Bussing and Lopez, 1977; Sydenham, 1977; Gorman and Karr, 1978; Schlosser, 1982; Angermeier and Karr, 1983; Winemiller, 1983; Perez, 1984; Angermeier and Schlosser, 1989; Hugueny, 1990; Winemiller and Leslie, 1992; Paller, 1994; Mérigoux et al., 1998; TejerinaGarro, 2001) and in environmental stability (Horwitz, 1978; Matthews and Styron, 1981; Grossman et al., 1982; Schlosser, 1987; Poff and Ward, 1989; Schlosser and Ebel, 1989; Poff and Allan, 1995). Indeed, rivers are highly variable environments and are periodically subjected to extreme and often unpredictable fluctuations in their physical and chemical characteristics (e.g. flow, temperature, dissolved oxygen, $\mathrm{pH}$, conductivity) and these fluctuations have been shown to affect the richness and structure of river fish assemblages (Horwitz, 1978; Grossman, 1982; Grossman et al., 1982, 1985, 1990, 1998; Schlosser, 1985; Merona, 1986; Schlosser and Ebel, 1989; Henderson and Walker, 1990; Poff and Allan, 1995; Landivar, 1995; Agostinho and Zalewski, 1995; Tito de Morais et al., 1995; Carrel and Rivier, 1996; Danehy et al., 1998; Lamouroux et al., 1999; Oberdorff et al., 2001b; TejerinaGarro, 2001; Fialho 2002) by leading to local population extinctions, individual immigration and emigration in response to current conditions and through recruitment success (Freeman et al., 1988; Carrel and Rivier, 1996). Furthermore, the importance of intradrainage immigration in shaping assemblage richness and structure has been emphasized by Osborne and Wiley (1992). These authors observed that within a river basin, a higher local species richness occurred in sites belonging to tributary streams located lower in a drainage network and connected to a main channel system than from similarly sized streams located in the headwaters of a drainage network. The potential mechanism responsible for this observed pattern was related to the immigration-extinction hypothesis (i.e. there should be a higher immigration rate in sites connected to the main channel which is assumed to be the colonization source).

These results suggest that extinction and colonization at the local scale are important processes in shaping fish assemblages and that environmental factors leading to temporal variability in populations size (e.g. discharge variability) are key components in explaining local fish assemblage structure and richness. However, the majority of the above studies mainly focused on species richness patterns without addressing explicitly the potential role of environmental factors on the functional aspect of these assemblages. Major exceptions are the studies of Rahel and Hubert (1991), Oberdorff et al. (1993), Belliard et al. (1997), Mérigoux et al. (1998), Smogor and Angermeier (1999), Tejerina-Garro (2001) in lotic systems and Rodriguez and Lewis Jr. (1997) in lentic systems, which provided support for environmental factors effects on trophic and reproductive attributes of fish assemblages. Therefore, one can reasonably expect that functional attributes of fish assemblages would be related, as for species richness, to natural environmental gradients.

\section{PROCESSES OCCURRING AT THE REGIONAL LEVEL}

Patterns and processes observed in local fish assemblages are not only determined by local mechanisms acting within assemblages, but also result from processes operating at larger spatial scales (Hugueny and Paugy, 1995; Hugueny et al., 1997; Angermeier and Winston, 1998; Oberdorff et al., 1998, Jackson et al., 2001). The richness and structure of local fish assemblages has been linked to factors ranging from geomorphology and climate (Nelson et al., 1992; Hughes et al., 1987; Whittier et al., 1988; Matthews and Matthews, 2000; Tejerina-Garro, 2001), to richness of regional species pool (Hugueny and Paugy, 1995; Hugueny et al., 1997; Belkessam et al., 1997; Angermeier and Winston, 1998; Oberdorff et al., 1998; Gido and Brown, 1999). Concerning this 
last relationship (local/regional richness) the emerging pattern is that few fish assemblages are trully saturated (Hugueny and Paugy 1995, Hugueny et al., 1997; Belkessam et al., 1997; Oberdorff et al., 1998). For example, Oberdorff et al. (1998) working on local fish assemblages of coastal streams of North-Western France found that these assemblages were unsaturated with species and with individuals and that inter-annual changes in populations were not strongly affected by densities of co-occurring species. Obviously in this study competition was not the main force driving these assemblages. Gido and Brown (1999) analysing colonization patterns by introduced freshwater fishes in 125 drainages across temperate North America, suggested that North American fish communities were not saturated in species, but instead, were capable of supporting higher levels of diversity if the pool of potential colonists and the rate of colonization from that pool was increased by species introduction. Then, studying local species assemblages in isolation cannot discover the determinants of local assemblage structure and richness, and the principal direction of control for local assemblage structure and richness is from regional to local (Cornell and Lawton, 1992; Lawton, 2000).

\section{ROLE OF BIOTIC FACTORS COMPETITION AND PREDATION}

An important question is to what extent predation and interspecific competition structure local riverine fish assemblages? The knowledge about it remains somewhat superficial even if some authors have suggested that these interactions may be strong enough to have pervasive effects (Werner, 1984, Jackson et al., 2001). However, there is little evidence that either predation or interspecific competition strongly affects local fish assemblages in rivers with the exception of few studies (Zaret and Rand, 1971; Schut et al., 1984; Wikramanayake and Moyle, 1989; Taylor, 1996; Resetarits, 1997, Jackson et al. 2001).

If we first consider interspecific competition, we can hypothesize that if this is really an important process, then it should set an upper limit to the number of species in an assemblage (another species could only be accommodated by the loss of a species). This hypothesis can be tested, for example, when introductions take place in a river.
Relative to this point, results of different studies previously detailed above show that local and regional fish communities are usually not saturated with species and are capable of supporting greater number of species if the pool of potential colonists and the rate of colonization from that pool was increased by species introduction (Belkessam et al., 1997; Angermeier and Winston, 1998; Oberdorff et al., 1998; Gido and Brown, 1999). These results strongly suggest that competition does not set the species saturation level in the assemblages studied and thus that competition is not a major force structuring these fish assemblages.

If we now consider predation, different studies have shown that this process can affect the choice of habitat by prey species within a river (Gorman, 1988; Schlosser and Angermeier, 1990). In tropical regions, mainly floodplain lakes, results suggest that predation is the mechanism responsible for fish structure in response to water transparency changes (Rodriguez and Lewis Jr., 1994, 1997). In other words, in some cases, fish assemblages' structure could be due to prey species' common avoidance of predators. Nevertheless, studies concerning competition or predation have noticed effects only on limited range of species combinations and thus are unable to provide real evidence that one of them is a major factor in organizing species assemblages.

\section{SYNTHESIS}

Table 1, even if obviously non-exhaustive, shows the significant relationships between local riverine fish assemblages and different environmental factors. Of the factors examined, we found the most consistent patterns of local assemblage structure and richness related to measures of river size (e.g. distance from sources, basin area, stream order, river width), elevation, river gradient, water velocity, depth, temperature, conductivity, habitat diversity, flow regimes, ecoregions and/or regional richness (i.e. pool of potential colonists). Relationships with competition and/or predation (biotic factors) were more equivocal. However, in this case it is necessary to point out the influence of the spatial scale used in each study considered in this paper. That is, small-scale studies usually indicate a greater importance of competition is structuring fish assemblages while large-scale 
studies usually emphasize abiotic controls (Jackson et al., 2001).

Another possible explanation for the noticed weak effect of predation and competition in structuring local assemblages could come from the predominance of studies carried out in temperate zones (compared to tropical ones) where fish fauna (e.g. Europe, North America) is reduced in richness due to historical processes (Mahon, 1984; Oberdorff et al., 1997) and where few congeneric species co-exist. If we assume that congeneric species have similar ecological niches (closely related species) then they should be strong competitors and competitive exclusion or density adjustments should occur more often among congeneric species than in more distantly related ones. Then we can suppose that competition is more common in tropical zones compared to temperate ones (Ricklefs, 1993). Nevertheless, more studies are needed to quantify this effect and its possible impact on assemblage structure in tropical rivers. Thus, apparently development of accurate biological indicators will have to integrate the relevant environmental factors to obtain a response of fish assemblages to human stressors that can be discriminated from natural variation.

\section{FISH-BASED METHODS CURRENTLY AVAILABLE}

There are relatively few ecological tools based on fish assemblages that uses structural and functional components of fish assemblages for assessment of river condition in temperate and tropical rivers. Two major approaches (tools) can be distinguished. Both use the "reference condition approach" (Bailey et al., 1998), which involves testing an ecosystem exposed to a potential stress against a reference condition that is unexposed to such a stress. Most common way is to select the reference sites that are "minimally disturbed" because pristine conditions no longer exist in most industrialized countries and coming back to prehistoric conditions first, will deny the place of humans in the landscape (Norris and Thoms, 1999) and second, will make restoration goals obsolete because obviously not attainable.

Table 1 - Results of empirical studies that describe the effect of environmental factors or phenomenon on local fish assemblage structure at different spatial scales.

\begin{tabular}{|c|c|c|}
\hline $\begin{array}{c}\text { Scale } \\
\text { Factor } \\
\end{array}$ & Effect & No effect \\
\hline $\begin{array}{l}\text { Local (site) } \\
\text { Altitude }\end{array}$ & $\begin{array}{l}\text { Beecher et al., 1988; Lauzanne et al., 1991*; Rahel and } \\
\text { Hubert, 1991; Mastrorillo et al., 1998; Angermeier and } \\
\text { Winston, 1998; Oberdorff et al., 2001a }\end{array}$ & $\begin{array}{l}\text { Maret et al., } 1997 \text {; } \\
\text { Waite and Carpenter, } \\
2000\end{array}$ \\
\hline $\begin{array}{l}\text { River size } \\
\text { Basin area } \\
\text { Distance from sources } \\
\text { River width } \\
\text { Stream order }\end{array}$ & $\begin{array}{l}\text { Huet, 1959; Sheldon, 1968; Bussing and Lopez, 1977*; } \\
\text { Sydenham, 1977*; Horwitz, 1978; Lauzanne and Loubens, } \\
\text { 1988*; Angermeier and Karr, 1983*; Winemiller, 1983*; } \\
\text { Mahon, 1984; Balon et al., 1986; Hugues and Gammon, } \\
\text { 1987; Beecher et al., 1988; Matthews and Robinson, 1988; } \\
\text { Paugy et al., 1988*; Ibarra and Stewart, 1989; Hugueny, } \\
\text { 1990*; Lyons and Schneider, 1990*; Osborne and Wiley, } \\
\text { 1992; Winemiller and Leslie, 1992*; Oberdorff et al., 1993; } \\
\text { Lyons, 1996; Belliard et al., 1997; Maret et al., 1997; } \\
\text { Mastrorillo et al., 1998; Kamdem-Toham and Teugels, } \\
\text { 1997*; Mérigoux et al., 1998*; Angermeier and Winston, } \\
\text { 1998; Matthews and Matthews, 2000; Tejerina Garro, 2001* }\end{array}$ & Mérona, 1981* \\
\hline River gradient & $\begin{array}{l}\text { Huet, 1959; Lyons, 1996; Maret et al., 1997; Mastrorillo et } \\
\text { al., 1998; Waite and Carpenter, 2000; Oberdorff et al., 2001 }\end{array}$ & \\
\hline Water velocity & $\begin{array}{l}\text { Hugueny, 1990*; Angermeier and Schlosser, 1989*; } \\
\text { Lamouroux et al., 1999; Matthews and Matthews, 2000; } \\
\text { Oberdorff et al., 2001 }\end{array}$ & \\
\hline
\end{tabular}




\begin{tabular}{|c|c|c|}
\hline Habitat diversity \$ & $\begin{array}{l}\text { Gorman and Karr, 1978*; Schlosser, 1982; Perez, 1984*; } \\
\text { Angermeier and Schlosser, 1989*; } \\
\text { Kamdem-Toham and Teugels, 1997*; Mérigoux et al., } \\
\text { 1998*; Tejerina-Garro, 2001* }\end{array}$ & Grossman et al., 1998 \\
\hline Depth & $\begin{array}{l}\text { Sheldon, 1968; Evans and Noble, 1979; Schlosser, 1982; } \\
\text { Gorman, 1988; Hugueny, 1990*; } \\
\text { Winemiller and Leslie, 1992*; Taylor et al., 1993; Matthews } \\
\text { and Matthews, 2000; Oberdorff et al., 2001a }\end{array}$ & \\
\hline Conductivity & $\begin{array}{l}\text { Taylor et al., 1993; Kamdem-Toham and Teugels, 1997*; } \\
\text { Mérigoux et al., 1998*; Tejerina-Garro, 2001* }\end{array}$ & \\
\hline Temperature & $\begin{array}{l}\text { Verneaux, 1977; Baltz et al., 1982; Schlosser, 1987; Rathert } \\
\text { et al., 1999; Waite and Carpenter, } 2000\end{array}$ & \\
\hline Flow variability & $\begin{array}{l}\text { Horwitz, 1978; Meffe, 1984; Schlosser, 1985; Poff and } \\
\text { Allan, 1995; Grossman et al., 1998; Oberdorff et al., 2001b }\end{array}$ & \\
\hline $\begin{array}{l}\text { Competition and/or } \\
\text { Predation }\end{array}$ & $\begin{array}{l}\text { Zaret and Rand, 1971*; Fausch and White, 1981; Baltz et al., } \\
\text { 1982; Schut et al., 1984*; Gorman, 1988; Wikramanayake } \\
\text { and Moyle, 1989*; Taylor, 1996; Resetarits, } 1997\end{array}$ & $\begin{array}{l}\text { Schlosser, 1982; } \\
\text { Oberdorff et al., 1998; } \\
\text { Grossman et al., 1998; } \\
\text { Gido and Brown, 1999; } \\
\text { Oberdorff et al., 2001a } \\
\end{array}$ \\
\hline $\begin{array}{l}\text { Regional (basin) } \\
\text { Ecoregion/Physiography } \\
\text { Hydrological units }\end{array}$ & $\begin{array}{l}\text { Hughes et al., 1987; Hughes et al., 1998; Matthews and } \\
\text { Robinson, 1988; Whittier et al., 1988; } \\
\text { Nelson et al., 1992; Belliard et al., 1997; Oberdorff et al., } \\
\text { 2001a }\end{array}$ & \\
\hline Basin richness & $\begin{array}{l}\text { Beecher et al., 1988; Hugueny and Paugy, 1995*; Belkessam } \\
\text { et al., 1997; Hugueny et al., 1997*; } \\
\text { Angermeier and Winston, 1998; Matthews and Robinson, } \\
\text { 1988; Oberdorff et al., 1998 }\end{array}$ & $\begin{array}{l}\text { Matthews and } \\
\text { Matthews, } 2000\end{array}$ \\
\hline
\end{tabular}

\$ usually measured in three dimensions: depth, water velocity and substrate; * tropical studies

\section{THE INDEX OF BIOTIC INTEGRITY (IBI)}

The first approach to quantify the impact of human activities on the aquatic ecosystem is a multimetric index, the Index of Biotic Integrity (IBI), first formulated by Karr (1981) and latter refined by Karr et al. (1986) for use in Midwestern USA streams. The IBI is based on the hypothesis that there are predictable relationships between fish assemblage structure and the physical, chemical and biological condition of stream systems. The IBI employs a series of metrics based on assemblage structure that give reliable signals of river condition to calculate an index score at a site, which is then compared to the score expected at an unimpaired comparable site. Classes of metrics in the IBI include species richness, species composition, trophic structure, total fish abundance, and individual fish condition (Table 2). Each metric reflects the quality of a different aspect of the fish assemblage that responds in a different manner to aquatic ecosystem stressors (Hughes and Noss, 1992). The combination of metrics reflects insights from individual, population, assemblage, ecosystem and zoogeographic perspectives.

The IBI methodology is outlined in Table 3. The primary underlying assumptions of the IBI concept are presented in Table 4. Since its introduction, the IBI has been modified for use in other regions and types of ecosystems throughout North America (Karr and Chu, 1999). It has also been modified for use outside North America (Hughes and Oberdorff, 1999) on six continents: Europe 
(Oberdorff and Hughes, 1992; Oberdorff and Porcher, 1994; Berrebi dit Thomas et al., 1998; and Belliard et al., 1999 in France; Kestemont et al., 2000 and Belpaire et al., 2000 in Belgium, Kesminas and Virbickas, 2000 in Lithuania), Africa (Hugueny et al., 1996 in Guinea, Hocutt et al., 1994 on the Namibia-Angola border, Hay et al., 1996 in Namibia, Kamdem-Toham and Teugels, 1999 in Gabon), Asia (Ganasan and Hughes, 1998 in India), Australia (Harris, 1995), Central America (Lyons et al., 1995 in Mexico) and South America (Gutierrez, 1994 in Venezuela;
Araújo, 1998 in Brazil; Tejerina-Garro, 2001 in French Guiana). In South America, the index adaptations made by Gutierrez (1994) and Araújo (1998) have conserved the same metrics as used in temperate regions. However, a new approach was used in French Guiana (South America), which selected the metrics to be used based on an empirical study of the interaction fish faunahabitat using taxonomical and functional descriptors (Tejerina-Garro, 2001).

Table 2 - IBI metrics for Midwestern USA streams (from Karr et al., 1986; Miller et al., 1988). ${ }^{\text {a}}$ Value approximates (5), deviates somewhat (3), or deviates strongly (1) from the reference condition; ${ }^{\mathbf{b}}$ Expected value varies with stream size, region, and basin; ${ }^{\mathbf{c}}$ Adult diets typically include $\geq 25 \%$ plant and $\geq 25 \%$ animal material; ${ }^{\mathbf{d}}$ Adult diets usually composed largely of aquatic vertebrates or crayfish; ${ }^{e}$ Disease, eroded fins, lesions, tumors, discoloration, excessive mucous, skeletal abnormalities, missing organs, and other external symptoms.

\begin{tabular}{llccc}
\hline Category & \multicolumn{3}{c}{ Scoring Criteria } \\
\cline { 2 - 4 } Metric
\end{tabular}

\section{Species Richness}

1. Total number of fish species

2. Number of darter species

3. Number of sunfish species

4. Number of sucker species

\section{Habitat guilds}

5. Number of intolerant species

6. \% individuals as

green sunfish

\section{Trophic guilds}

7. \% individuals as omnivores $\mathbf{c}$

8. \% individuals as insectivorous cyprinids

9. \% individuals as piscivores $\mathbf{d}$

\section{Abundance}

10. Number of individuals

\section{Reproduction and Condition}

11. \% individuals as hybrids

12. \% individuals with anomalies $\mathbf{e}$ b

b

b

b

b

$<5$

$<20$

$>45$

$>5$

b

0

$0-2$

$\mathbf{b}$
$\mathbf{b}$
$\mathbf{b}$
$\mathbf{b}$

b

b

b

b

\section{b}

$5-20$

$>20$

$20-45$

$>45$

$20-45$

$1-5$

$<1$

b

$>1$

$>5$
Even if these applications attest to the utility of the concept (Karr and Chu, 1999), it should be noticed anyway that none of these studies (except Belliard et al., 1999 and Tejerina-Garro, 2001) truly validated the methodology with independent datasets of both disturbed and reference sites.
Properly developed IBI's usually incorporate region-specific metrics and adjust metric criteria (usually only for taxonomic metrics) by river size (e.g. stream order or catchment's area) to isolate natural versus anthropogenic influences on local fish assemblage structure. Region-specific criteria 
are set using broad regional land classification (e.g. ecoregions). The basis of this approach is the understanding that the character of a river (e.g. its water quality, flow regime, habitat structure, energy base) is in large part a function of the climate, topography, geology, soil, vegetation, and land use of its geographic region. Such an approach is efficient in grouping similar rivers (at least at some level of resolution), allowing the reduction of the natural regional variability.

\section{THE FISH-BASED INDEX (FBI)}

The second approach originates from a research program (1996-2000) initiated by the French Water Agencies and the Ministry of the Environment to develop a fish-based index that could be applicable nationwide (Oberdorff et al., 2001a; Oberdorff et al., 2002).

Such an index had to encompass the relative importance of potential regional and local processes influencing the distribution of riverine fish. Convinced that the IBI's concept was ecologically sound effective for assessment of the status, trends, and ecological integrity of a water body Oberdorff et al. (2001a, 2002) tried to improve the accuracy of such an index while maintaining its theoretical foundations. They did it by using the recent findings in aquatic ecology to distinguish, as far as possible, effects of anthropogenic disturbances from natural variation in assemblage structure and richness. The rational for the development of the FBI is summarized in Table 5 and detailed in Oberdorff et al. (2002).

Three independent data sets were used: 1) two sets of reference sites, fairly evenly distributed across French rivers; 2) a third set of exposed (disturbed) sites. A variety of metrics based on occurrence and abundance data and reflecting different aspects of the fish assemblage structure and function were selected from available litterature and for their potential to indicate degradation. For metrics based on species occurrences, logistic multiple regression procedures were applied, using the first data set of reference sites and defined by the main regional and local factors known to influence local fish assemblages (see Table 1) (i.e. drainage area, distance from sources, altitude, river gradient, water velocity, depth, temperature, and hydrological units), to elaborate the simplest possible response model that adequately explains the observed patterns of occurrence for each species of a fish assemblage for a given site of any given river.

For a given occurrence metric, a theoritical assemblage for each site is obtained by summing the predicted probability of each species included in the considered metric. For metrics based on abundance data, stepwise multiple regression procedures were applied to elaborate the simplest possible response model that adequately explains the observed value of each metric (i.e. the sum of log-transformed density of individuals belonging to species considered in the metric) for a given site of any given river. All models retained a majority of environmental factors underlying their importance in structuring local fish assemblages as discussed earlier. After eliminating metrics for which residuals distribution values statistically differed from a normal distribution using the initial data set of reference sites, and after converting residual values of the $\mathrm{n}$ metric models into probabilities, models obtained for each metric were validated using the two independent data sets of reference and disturbed sites. These procedures allowed to select the most effective metrics in discriminating between reference and disturbed sites (Table 6). Overall, the FBI performed well in discriminating beween reference and disturbed sites and in distributing sites along the gradient of perturbations (Fig. 2). It is thus a useful indicator of running-water ecosystems, which could be used to monitor change and provide a baseline for measuring the full biotic response to restoration of these rivers. Moreover, it can be applied in the different regions and river types of France using a consistent set of metrics despite the complex and heterogeneous geology and climate of that country.

The final index score was obtained by computing the combined probabilities corresponding to the remaining effective metrics. To avoid logical circularity, the optimal cut-off level for a local assemblage "impairment" was obtained by analysing distributions of index scores for the two independent data sets of reference and disturbed sites. 
Table 3 - Principles of fish assemblage assessment with the IBI (Modified after Hughes and Oberdorff, 1999).

1. Select a relatively homogeneous region. A region may be an ecoregion, basin, or fish faunal region that is homogeneous with respect to a combination of environmental characteristics (e.g., climate, physiography, soil, vegetation) and potential fish species.

2. Determine the reference condition(s). References may be a set of minimally disturbed reference streams, a disturbance gradient, historical data, paleoecological information, and professional judgement.

3. List candidate metrics and assign species to trophic, tolerance, and habitat guilds. Regional fish texts usually provide this information, at least in developed countries.

4. Sample fish assemblages. This is best done (a) when they are least variable yet most limited by anthropogenic stressors and (b) in a manner yielding a representative collection of species and proportionate abundances, but that (c) is cost-effective.

5. Tabulate numbers of individuals collected by species at each reach.

6. Calculate values for each candidate IBI metric. Typically these are proportions or percents of individuals, or numbers of species in particular categories.

7. Develop scoring criteria. These are based on previously available information from step 2 or from fish data collected at minimally disturbed sites in step 4 . Scoring criteria may be continuous $(0-1$ or $0-10)$ or based on classes $(1,3,5$ or $0,5,10)$. An IBI score represents comparisons between metric value at a sample site and those expected under reference conditions. Metric criteria are usually adjusted by river size.

8. Calculate metric scores and add these to obtain an IBI score.

9. Evaluate metric and index scores. Consider, differences between expected and obtained scores, compare variance results from repeated samples, assess responsiveness to environmental stressors. Modify or reject metrics that are highly variable or unresponsive, and recalculate if necessary.

10. Interpret IBI score as indicating an acceptable, marginally impaired, or highly impaired fish assemblage; or as excellent, good, fair, poor, very poor.

Table 4 - Assumed effects of environmental degradation on fish assemblages (from Fausch et al., 1990 and Hughes

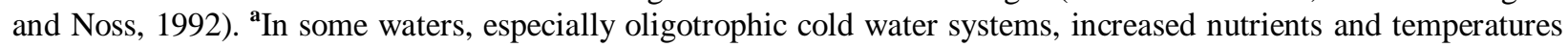
often result in additional species and individuals.

Number of native species and of those in specialized taxa or guilds declines ${ }^{\mathbf{a}}$

Number of sensitive species declines

$\%$ of trophic and habitat specialists declines

Total number of individuals declines ${ }^{\mathrm{a}}$

$\%$ of large individuals and the number of size classes decrease

$\%$ of tolerant individuals increases

$\%$ of trophic and habitat generalists increases

$\%$ individuals with anomalies increases 
Table 5 - General principles of fish assemblage assessment with the FBI (Oberdorff et al., 2002).

1. Determine the reference condition(s)

2. List candidate metrics and assign species to trophic, tolerance, and habitat guilds based on literature review

3. Model metrics in relation to regional and local environmental factors. The method is designed to predict a metric value at a particular reference site, independent of natural environmental factors. Eliminate metrics not adequately modelised

4. Validate the models using independent data sets of reference and disturbed sites in order to select the most effective metrics in discriminating between reference and disturbed sites (reject metrics that are highly variable or unresponsive)

5. Add metrics values to obtain an index score

6. Develop scoring criteria

7. Interpret index score as excellent, good, fair, poor, very poor

Table 6 - Fish assemblage metrics used to calculate the FBI for French rivers (after Oberdorff et al., 2002).

\begin{tabular}{ll}
\hline \multicolumn{1}{c}{ Category } & \multicolumn{1}{c}{ Metrics } \\
\hline Taxonomic richness & 1. Total number of species \\
Habitat composition & 2. Number of reophilic species \\
3. Number of lithophilic species & 4. Tolerant species individuals \\
Trophic composition & \\
& 5. Invertivorous species individuals \\
Fish abundance & 7. Total density of individuals \\
\hline
\end{tabular}

\section{ADVANTAGES AND DISADVANTAGES OF BOTH INDEX}

Both index have several advantages in common. They are broadly based ecological indexes that assess both assemblage structure and function at several trophic levels; they are flexible and widely adaptable and combine several types of metrics (e.g. taxonomic, reproductive, trophic and tolerance metrics) that individually provide different responses to perturbations. Consequently, they are responsive to general types of degradation, and should then be able to quantify the biological effects of human activities on aquatic ecosystems.

The main difference between the FBI and the IBI methodologies lies on the way metric (fish assemblage attributes) criteria are adjusted (i.e. the expected value of a metric for a given site under conditions least affected by anthropogenic disturbance). As previously mentioned, the IBI approach consists in adjusting species richnessmetric (e.g. total species richness, number of tolerant species, number of benthic species) criteria exclusively on the basis of empirical relations between river size (i.e. position of a given site along the upstream-downstream gradient) and taxa richness. Nevertheless, stratifying intra-regional criteria by using only a single factor like river size is clearly inadequate as previoulsly discussed in this paper (see Table 1). Moreover, most of the time, abundance related metrics (i.e functional metrics such as total number of individuals, proportional abundance of omnivores, proportional abundance of lithophilic individuals) are not adjusted at all suggesting that these metrics are invariant across river sizes or 
other environmental factors. Ignoring potential relations between environmental factors and these last metrics seems contrary to evidence that such relations exist (see Table 1). For example, the River Continuum concept (Vannote et al., 1980) explicitly predicts changes in fish trophic structure along a longitudinal gradient. This concept attempts to relate the gradient in physical factors that occurs along river systems, to change in assemblage structure and function. According to this concept, available food resources should change along this gradient and thus should be reflected by the trophic composition of the assemblages. These predictions have been confirmed for fish assemblages in French river by Oberdorff et al. (1993) (i.e. a decrease in invertivorous species and an increase in omnivorous species from upstream to downstream). Moreover, Oberdorff et al. (2002), provided empirical support that other functional metrics varied with river size and other environmental factors. Oberdorff et al. (2002) used predictive models to assess the response of local assemblage attributes (metrics) to natural environmental gradients. The environmental variables selected correspond to five categories of environmental attributes of sites (i.e. river size (measured by a combination of drainage area and distances from sources), altitude, water velocity (measured by a combination of river width, river depth and river gradient) temperature, and hydrological units). All five attributes appeared critical in predicting metrics value for a given site. Although the predictor factors for each of the metric models were slightly different, all models included factors that incorporate information on each of these five attributes (Table 7).
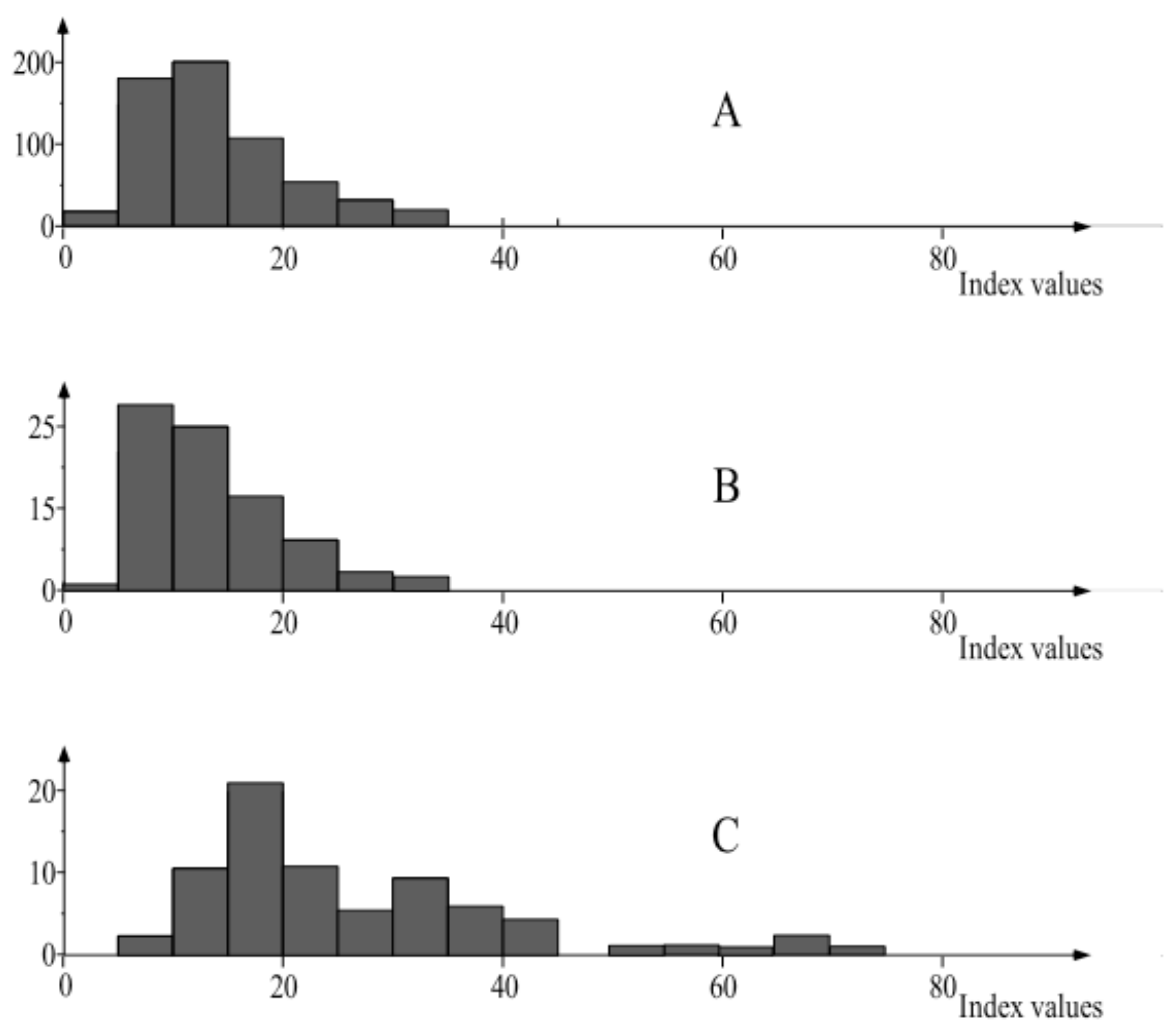

Figure 2 - Distribution of the index scores for the three independent data sets. (A) and (B) reference sites, (C) disturbed sites. From Oberdorff et al. (2002). 
Thus, it is clear that to set appropriate metric criteria, one should compare how metrics vary with river size relative to how they differ across regions and/or drainages, and relevant local environmental gradients within each. This type of approach appears to be of importance for elaboration of an accurate biological indicator. This strategy was adopted for the EC research programme (FAME, 2001-2004; http://www. fame.boku.ac.at) to develop a fish-based assessment method for the ecological status of European rivers.

Table 7 - Commonly used predictor factors for FBI models. *Total number of predictive models tested=38.

\begin{tabular}{lc}
\hline Scale & Number of models*integrating factor as a predictor \\
Factor & 24 \\
Altitude & 36 \\
River size & \\
Basin area & 27 \\
Distance from sources & \\
Water velocity & \\
River width & \\
River gradient & 33 \\
Depth & \\
Temperature & 26 \\
Regional & \\
Hydrological units & \\
\hline
\end{tabular}

\section{CONCLUSIONS}

The ability to protect biological resources relies on the ability to identify and predict the effects of human activities on biological systems. This depends first on the capacity in distinguishing between natural and human-induced variation in biological condition. To achieve this goal, it is important for researchers to continue to develop and improve multimetric fish-based indexes by accounting for the many possible sources of inter and intraregional variation in assemblages structure in natural conditions. A special attention should be given to analyse natural environmental effects on functional metrics, which has been until now too often neglected. Accounting for these natural variations will greatly enhance index's intented function, i.e., to solely reflect anthropogenic disturbance effects (Smogor and Angermeier, 1999).

\section{ACKNOWLEDGMENTS}

We thank grants from the Institut de Recherche pour le Développement (IRD), France, the EU FAME project (Contract $\mathrm{n}^{\circ}$ EVK1-CT-200100094); the Universidade Católica de Goiás, Brazil (Project $\mathrm{n}^{\circ}$ 84-VPG/UCG) and the Universidad Mayor de San Simón (Bolivia).

\section{RESUMO}

A água dos rios constituem um recurso básico para a humanidade. Instrumentos biológicos eficaces (com fundamento ecológico, eficientes, rápidos e aplicáveis à regiões ecologicamente diferentes) são necessários para medir a "saúde" destes. Adaptar tais instrumentos a uma grande área geográfica requer uma compreensão detalhada dos padrões da composição da assembléia de organismos e da sua distribuição dentro e entre os corpos da água em condições naturais, e da natureza dos principais gradientes ambientais que causam ou explicam estes padrões. Uma revisão da literatura disponível pode ajudar a identificar os fatores ambientais mais consistentes que estruturam a assembléia de peixes de ambientes lóticos em condições naturais.

\section{REFERENCES}

Agostinho, A. A. and Zalewski, M. (1995), The dependence of fish community structure and dynamics on floodplain and riparian ecotone zone in Parana River, Brazil. Hydrobiologia, 303, 141-148.

Angermeier, P. L. and Karr, J. R. (1983), Fish communities along environmental gradients in a system of tropical streams. Environmental Biology of Fishes, 9, 117-135. 
Angermeier, P. L. and Schlosser, I. J. (1989), Species area relationships for stream fishes. Ecology, 70, 1450-1462.

Angermeier, P. L. and Winston, M. R. (1998), Local vs. Regional influences on local diversity in stream fish communities of Virginia. Ecology, 79, 911-927.

Araújo, E. G. (1998), Adaptação do índice de integridade biótica usando a comunidade de peixes para o rio Paraíba do Sul. Rev. Brasil. Biol., 58, 547-558.

Bailey, R. C.; Kennedy, M. G.; Dervish, M. Z. and Taylor, R. M. (1998), Biological assessment of freshwater ecosystems using a reference approach: comparing predicted and actual benthic invertebrate communities in Yukon streams. Freshwater Biology, 39, 765-774.

Balon, E. K.; Crawford, S. S. and Lelek, A. (1986), Fish communities of the upper Danube River (Germany, Austria) prior to the new Rhein-Main-Donau connection. Environmental Biology of Fishes, 15, 243-271.

Baltz, D. M.; Moyle, P. B. and Knight, N. J. (1982), Competitive interactions between benthic stream fishes: riffle sculpin Cottus gulosus, and speckled dace, Rhinicthys osculus. Canadian Journal of Fish and Aquatic Sciences, 39, 1502-1511.

Beecher, H. A.; Dott, E. R. and Fernau, R. F. (1988), Fish species richness and stream order in Washington State streams. Environmental Biology of Fishes, 22, 193-209.

Belkessam, D.; Oberdorff, T. and Hugueny, B. (1997), Unsaturated fish assemblages in rivers of the NorthWestern France : potential consequences for species introductions Bulletin Français de Pêche et Pisciculture, 344/345, 193-204.

Belliard, J.; Berrebi dit Thomas, R. and Monnier, D. (1999), Fish communities and river alteration in the Seine Basin and nearby coastal streams. Hydrobiologia, 400, 155-166.

Belliard, J.; Boët, P. and Tales, E. (1997), Regional and longitudinal patterns of fish community structure in the Seine River basin, France. Environmental Biology of Fishes, 50, 133-147.

Belpaire, C.; Smolders, R.; Vanden Auweele, I.; Ercken, D.; Breine J., Van Thyne, G. and Ollevier, F. (2000), The index of biotic integrity characterizing fish populations and ecological quality of Flandrian water bodies. Hydrobiologia, 434, 17-33.

Berrebi dit Thomas, R.; Belliard J. and Boët P. (1998), Caractéristiques des peuplements piscicoles sensibles aux altérations du milieu dans les cours d'eau du bassin de la Seine. Bulletin Français de Pêche et Pisciculture, 348, 47-64.

Bussing, W. A. and Lopez, M. I. (1977), Distribución y aspectos ecologicos de los peces de las cuencas hidrograficas de Arenal Bebedero y Tempisque, Costa Rica. Revista de Biologia Tropical, 25, 13-37.
Carrel, G. and Rivier, B. (1996), Distribution of three euryoecious cyprinids in the main channel of the Lower River Rhône. Archiv Für Hydrobiologie, 113, 363-374.

Cornell, H. V. and Lawton, J. H. (1992), Species interactions, local and regional processes, and limits to the richness of ecological communities: a theoretical perspective. Journal of Animal Ecology, 61, 1-12.

Danehy, R. J.; Ringler, N. H.; Stehman, S. V. and Hasset, J. M. (1998), Variability of fish densities in a small catchment. Ecology of Freshwater Fish, 7, 36-48.

Evans, J. W. and Noble, R. L. (1979), The longitudinal distribution of fishes in an east Texas stream. American Midland Naturalist, 101, 333-334.

Fausch, K. D. and White, R. J. (1981), Competition between brook trout (Salvelinus fontinalis) and brown trout (Salmo trutta) in a Michigan stream. Canadian Journal of Fish and Aquatic Sciences, 38, 1220-1227.

Fausch, K. D.; Lyons, J.; Karr, J. R. and Angermeier, P. L. (1990), Fish communities as indicators of environmental degradation. In Biological indicators of stress in fish. American Fisheries Society Symposium 8, Bethesda, Maryland, USA, 8, 123-144.

Ferguson, R. G. (1958), The preferred temperature of fish and their midsummer distribution in temperate lakes and streams. J. Fish. Res. Bd. Can, 15, 607-624.

Fialho, A. P. (2002), Ecologia da comunidade ictiofaunística da bacia do rio Meia Ponte. Master thesis. Universidade Federal de Goiás. 60 p.

Freeman, M. C.; Crawford, M. K.; Barrett, J. C.; Facey, D. E.; Flood, M. G.; Hill, J.; Stouder, D. J. and Grossman, G. D. (1988), Fish assemblage stability in a Southern Appalachian stream. Canadian Journal of Fish and Aquatic Sciences, 45, 1949-1958.

Ganasan, V. and Hugues, R. M (1998), Application of an index of biological integrity (IBI) to fish assemblages of the rivers Khan and Kshipra (Madhya Pradesh), India. Freshwater Biology, 40, 367-383.

Gido, K. B. and Brown, J. H. (1999), Invasion of North American drainages by alien fish species. Freshwater Biology, 42, 387-399.

Gorman, O. T. and Karr, J. R. (1978), Habitat structure and stream fish communities. Ecology, 59, 507-515.

Gorman, O. T. (1988), An experimental study of habitat use in an assemblage of Ozark minnows. Ecology, 69, 1239-1250.

Grossman, G. D. (1982), Dynamics and organization of a rocky intertidal fish assemblage: the persistence and resilience of taxocene structure. American Naturalist, 119, 611-637.

Grossman, G. D.; Dowd, J. F. and Crawford, M. (1990), Assemblage stability in stream fishes: a review. Environmental Management, 5, 661-671. 
Grossman, G. D.; Freeman, M. C.; Moyle, P. B. and Whittaker, J. O. (1985), Stochasticity and assemblage organization in an Indiana stream fish assemblage. American Naturalist, 126, 275-285.

Grossman, G. D.; Moyle, P. B. and Whittaker, J. O. (1982), Stochasticity in structural and functional characteristics of an Indiana stream fish assemblage: a test of community theory. American Naturalist, 120, 423-454.

Grossman, G.; Ratajczac, R. E.; Crawford, M. and Freeman, M. C. (1998), Assemblage organization in stream fishes: effects of environmental variation and interspecific interactions. Ecological Monographs, 68, 395-420.

Gutierrez, M. A. R. (1994), Utilización de la ictiofauna como indicadora de la integridad biótica de los rios Guache y Guanare, Estado Portuguesa, Venezuela. Master thesis. Universidad Nacional Experimental de los Llanos Occidentales "Ezequiel Zamora". 144 pp.

Harris, J. H. (1995),. The use of fish in ecological assessments. Australian Journal of Ecology, 20, 65-80.

Hay, C. J.; van Zyl, B. J. and Steyn, G. J. (1996), A quantitative assessment of the biotic integrity of the Okavango River, Namibia, based on fish. Water SA, 22, 263-284.

Henderson, P. A. and Walker, I. (1990), Spatial organization and population density of the fish community of the litter banks within a central Amazonian blackwater stream. Journal of Fish Biology, 37, 401-411.

Hocutt, C. H.; Johnson, P. N.; Hay, C. and Van Zyl Ben, J. (1994), Biological basis of water quality assessment: the Kavango River, Namibia. Rev. Hydrobiol. trop., 27 : (4), 361-384

Horwitz, R. J. (1978), Temporal variability patterns and the distribution patterns of stream fishes. Ecological Monographs, 48, 307-321.

Huet, M. (1959), Profiles and biology of Western European streams as related to fish management. Transaction of the American Fisheries Society, 88, 155-163.

Hughes, R. M. and Gammon, J. R. (1987), Longitudinal changes in fish assemblages and water quality in the Willamette River, Oregon. Transaction of the American Fisheries Society, 116, 196-209.

Hughes, R. M. and Noss, R .F. (1992), Biological diversity and biological integrity: current concerns for lakes and streams. Fisheries, 17, 11-19.

Hughes, R. M. and Oberdorff, T. (1999), Applications of IBI Concepts and Metrics to Waters Outside the United States and Canada. Pages 79-83. In: Thomas P. Simon (Ed.). Assessment Approaches for Estimating Biological Integrity using Fish Assemblages. Lewis Press, Boca Raton, FL, USA.
Hughes, R. M.; Kaufmann, P. R.; Herlihy, A. T.; Kincaid, T. M.; Reynolds, L. and Larsen, D. P. (1998), A process for developing and evaluating indices of fish assemblage integrity. Canadian Journal of Fisheries and Aquatic Sciences, 55, 1618-1631.

Hughes, R. M.; Rexstad, E. and Bond, C. E. (1987), The relationship of aquatic ecoregions, river basins, and physiographic provinces to the ichtyogeographic regions of Oregon. Copeia, 1987, 423-432.

Hugueny, B. (1990), Richesse des peuplements de poissons dans le Niandan (haut Niger, Afrique) en fonction de la taille de la rivière et de la diversité du milieu. Revue Hydrobiologie Tropicale, 23, 351-364.

Hugueny, B.; Camara, S.; Samoura, B. and Magassouba, M. (1996), Applying an index of biotic integrity based on fish assemblages in a West African river. Hydrobiologia, 331, 71-78.

Hugueny, B.; Tito de Morais, L.; Mérigoux, S.; Mérona, B. and Ponton, D. (1997), The relationship between local and regional species richness: comparing biotas with different evolutionary histories. Oikos, 80, 583-587.

Hugueny, B and Paugy, D. (1995), Unsaturated fish communities in African rivers. American Naturalist, 146, 162-169.

Ibarra, M. and Stewart, D. J. (1989), Longitudinal zonation of sandy beach fishes in the Napo river basin, Eastern Ecuador. Copeia, 2, 364-389.

Jackson, D. A.; Peres-Neto, P. R. and Olden, J. D. (2001), What controls who is where in freshwater fish communities - the roles of biotic, abiotic, and spatial factors. Can. J. Fish. Aquat. Sci. 58, 157-170.

Kamdem-Toham, A. and Teugels, G. G. (1997), Diversity patterns of fish assemblages in the Lower Ntem River basin (Cameroun), with notes on potential effects of deforestation. Arch. Hydrobiol., 141, 421-426.

Kamdem-Toham, A. and Teugels, G. G. (1999), First data on an Index of Biotic Integrity (IBI) based on fish assemblages for the assessment of the impact of deforestation in a tropical West African river system. Hydrobiologia, 397, 29-38.

Karr, J. R.; Fausch, K. D.; Angermeier, P. L.; Yant, P. R. and Schlosser, I. J. (1986), Assessing Biological Integrity in Running Waters: A Method and its Rationale . Illinois Natural History Survey Special Publication 5, Champaign, Illinois, USA.

Karr, J. R. and Chu, E. W. (1999), Restoring life in running waters: better biological monitoring. Island Press, Washington, DC, USA.

Karr, J. R. (1981), Assessment of biotic integrity using fish communities. Fisheries, 6, 21-27.

Kesminas, V. and Virbickas, T. (2000), Application of an adapted index of biotic integrity to rivers of Lithuania. Hydrobiologia, 422/423, 257-270. 
Kestemont, P.; Didier, J.; Depiereux, E. and Micha, J. C. (2000), Selecting ichtyological metrics to assess river basin ecological quality. Archiv Für Hydrobiologie, 121, 321-348.

Lamouroux N., Olivier J.M., Persat H., Pouilly M., Souchon Y. and Statzner B. (1999), Predicting community characteristics from habitat conditions: fluvial fish and hydraulics. Freshwater Biology, 42, 275-299.

Landivar J. (1995), Ecologie de la communauté de poissons et du chame (Dormitator latifrons) dans les rivières Vinces et Babahoyo (Equateur) et leur plaine d'inondation. Master thesis. Université du Québec à Montréal. 69 p.

Lauzanne L. and Loubens G. (1988), Estudios ictiológicos del convenio ORSTOM-UTBCORDEBENI en la Amazonia boliviana. Memorias Sociedad de Ciencias Naturales La Salle, 48, 387-407.

Lauzanne L., Loubens G. and Le Guennec B. (1991), Liste commentée des poissons de l'Amazonie bolivienne. Revue d'Hydrobiologie Tropicale, 24, 61-76.

Lawton J. H. (2000), Community ecology in a changing world. Ecological Institute, Oldendorf/Luhe, Germany.

Lyons J. and Schneider D. W. (1990), Factors influencing fish distribution and community structure in a small coastal river in South-Western Costa Rica. Hydrobiologia, 203, 1-14.

Lyons J. (1996), Patterns in the species composition of fish assemblages among Wisconsin streams. Environmental Biology of Fishes, 45, 329-341.

Lyons J., Navarro-Pérez S., Cochran P. A., Santana C. E. (1995), Index of Biotic Integrity based on fish assemblages for the conservation of streams and rivers in West-Central Mexico. Conservation Biology, 9(3), 569-584.

Mahon R. (1984), Divergent structure in fish taxocenes of north temperate streams. Canadian Journal of Fisheries and Aquatic Sciences, 41, 330-350.

Maret T. R., Robinson C. T. and Minshall G. W. (1997), Fish assemblages and environmental correlates in least-disturbed streams of the upper Snake River basin. Transactions of the American Fisheries Society, 126, 200-216.

Mastrorillo S., Dauba F., Oberdorff T., Guégan J. F. and Lek S. (1998), Predicting local fish species richness in the Garonne River basin. C. R. Acad. Sci. Paris (Life Sciences), 321, 423-428.

Matthews E. M. and Matthews W. J. (2000), Geographic, terrestrial and aquatic factors: which most influence the structure of stream fish assemblages in the midwestern United States? Ecology of Freshwater Fish, 9, 9-21.

Matthews W. J. and Robinson H. W. (1988), The distribution of the fish of Arkansas: a multivariate analysis. Copeia, 1988, 358-374.
Matthews W. J. and Styron J. T. (1981), Tolerance of headwaters vs. mainstream fishes for abrupt physicochemical changes. American Midland Naturalist, 105, 149-158.

Mazzoni R. and Lobon-Cervia J. (2000), Longitudinal structure, density and production of a neotropical stream fish assemblage: the river Ubatiba in the Serra do Mar, southeast Brazil. Ecography, 23(5), 588-602.

Meffe G. K. (1984), Effects of abiotic disturbance on coexistence of predator-prey fish species. Ecology, 65, 1525-1534.

Mérigoux S., Ponton D. and Mérona B. (1998), Fish richness and species-habitat relationships in two coastal streams of French Guiana, South America. Environmental Biology of Fishes, 51, 25-39.

Mérona B. (1981), Zonation ichtyologique du bassin du Bandama (Côte-d'Ivoire). Revue Hydrobiologie Tropicale, 14, 63, 75.

Mérona B. de. (1986), Aspectos ecologicos da ictiofauna no baixo Tocantins. Acta Amazonica, 16/17, 109-124.

Miller D. L., Leonard P. M., Hughes R. M., Karr J. R., Moyle P. B., Schrader L. H., Thompson B. A., Daniels R. A., Fausch K. D., Fitzhugh G. A., Gammon J. R., Halliwell D. B., Angermeier P. L. and Orth D. J. (1988), Regional applications of an index of biotic integrity for water resource management. Fisheries, 13, 12-30.

Nelson R. L., Platts W. S., Larsen D. P. and Jensen S. E. (1992), Trout distribution and habitat in relation to geology and geomorphology in the North Fork Humboldt river drainage, northeastern Nevada. Transactions of the American Fisheries Society, 121, 405-426.

Norris R. H. and Thoms M.C. (1999), What is river health? Freshwater Biology, 41, 197-209.

Oberdorff T. and Hughes R. M. (1992), Modification of an index of biotic integrity based on fish assemblages to characterize rivers of the Seine Basin, France. Hydrobiologia, 228, 117-130.

Oberdorff T., Guilbert E. and Luchetta J. C. (1993), Patterns of fish species richness in the Seine River basin, France. Hydrobiologia, 259, 157-167.

Oberdorff T., Hugueny B. and Guégan J. F. (1997), Is there an influence of historical events on contemporary fish species richness in rivers? Comparisons between Western Europe and North America. Journal of Biogeography, 24, 461-467.

Oberdorff T., Hugueny B. and Vigneron T. (2001b), Is assemblage variability related to environmental variability? An answer for riverine fish. Oikos, 93, 419-428.

Oberdorff T., Hugueny B., Compin A. and Belkessam D. (1998), Non-interactive fish communities in the coastal streams of North-Western France. Journal of Animal Ecology, 67, 472-484. 
Oberdorff, T.; Pont, D.; Hugueny, B. and Chessel, D. (2001a), A probabilistic model characterizing riverine fish communities of French rivers: a framework for environmental assessment. Freshwater Biology, 46, 399-415.

Oberdorff, T.; Pont, D.; Hugueny, B. and Porcher, J. P. (2002), Development and validation of a fish-based index for the assessment of rivers "health" in France. Freshwater Biology, 47, 1720-1735.

Oberdorff, T. and Porcher, J. P. (1994), An index of biotic integrity to assess biological impacts of salmonid farm effluents on receiving waters. Aquaculture, 119, 219-235.

Osborne, L. L. and Wiley, M. J. (1992), Influence of tributary spatial position on the structure of warmwater fish communities. Canadian Journal of Fisheries and Aquatic Science, 49, 671-681.

Paller, M. H. (1994), Relationships between fish assemblage structure and stream order in South Carolina coastal plain stream. Transactions of the American Fisheries Society, 123, 150-161.

Paugy, D.; Benech, V. and Etou, K. (1988), La faune ichtyologique des bassins du Mono et du lac Togo (Togo). ORSTOM, Bamako, 23, 1-110.

Perez, L. E. (1984), Uso del habitat por la comunidad de peces de un rio tropical asociado a un bosque. Memoria Sociedad Ciencias Naturales La Salle, XLIV, 121, 143-162.

Poff, N. L.; Allan, D.; Bain, M. B.; Karr, J. R.; Prestegaard, K. L.; Richter, B. D.; Sparks, R. E. and Stromberg J.C. (1997), The natural flow regime. A paradigm for river conservation and restoration. Bioscience, 47, 769-784.

Poff, N. L. and Allan, J. D. (1995), Functional organization of stream fish assemblages in relation to hydrological variability. Ecology, 76, 606-627.

Poff, N. L. and Ward, J. V. (1989), Implications of streamflow variability and predictability for lotic community structure: a regional analysis of streamflow patterns. Can. J. Fish. Aquat. Sci., 46, 1805-1818.

Pringle, C. M.; Scatena, F. N.; Paaby-Hansen, P. and Núñez-Ferrera. (2000), River conservation in Latin America and the Caribbean. In: Boon, P. J.; Davies, B. R. and Petts, G. E. (Eds.). Global perspectives on river conservation: science, policy and practice. John Wiley and Sons. Chichester. 548 pp.

Rahel, F. J. and Hubert, W. A. (1991), Fish assemblages and habitat gradients in a Rocky Mountain-Great Plains stream: biotic zonation and additive patterns of community change. Transactions of the American Fisheries Society, 120, 319-332.

Rathert, D.; White, D.; Sifneos, J. C. and Hughes, R. M. (1999), Environmental correlates of species richness for native freshwater fish in Oregon, USA. Journal of Biogeography, 26, 257-274.
Resetarits Jr., W. J. (1997), Interspecific competition and qualitative competitive asymmetry between two benthic stream fishes. Oikos, 78, 428-439.

Ricklefs, R. E. (1993), A economia da natureza. Guanabara Koogan S. A., Rio de Janeiro, 470 pp.

Rodríguez, M. A. and Lewis Jr., W. M. (1994), Regulation and stability in fish assemblages of neotropical floodplain lakes. Oecologia, 99, 166-80.

Rodríguez, M. A. and Lewis Jr., W. M. (1997), Structure of fish assemblages along environmental gradients in floodplain lakes of the Orinoco River. Ecological Monographs, 67 : (1), 109-28.

Schlosser, I. J. and Angermeier, P. L. (1990), The influence of environmental variability, resource abundance, and predation on juvenile cyprinid and centrarchid fishes. Polish Archives of Hydrobiology, 37, 265-284.

Schlosser, I. J. and Ebel, K. K. (1989), Effects of flow regime and cyprinid predation on a headwater stream. Ecological Monographs, 59, 41-57.

Schlosser, I. J. (1982), Fish community structure and function along two habitat gradients in a headwater stream. Ecological Monographs, 52, 395-414.

Schlosser, I. J. (1985), Flow regime, juvenile abundance, and the assemblage structure of stream fishes. Ecology, 66, 1484-1490.

Schlosser, I. J. (1987), A conceptual framework for fish communities in small warmwater streams. In- W.J. Matthews and D.C. Heins (eds.) Community and evolutionary ecology of North American stream fishes. University of Oklahoma Press, Norman, Oklahoma, USA. pp. 17-24

Schlosser, I. J. (1995), Critical landscape attributes that influence fish population dynamics in headwater streams. Hydrobiologia, 303, 71-81.

Schut, J.; De Silva, S. S. and Kortmulder, K. (1984), Habitat, associations and competition of eight Barbus (=Puntitus) species (Pisces, Cyprinidae) indegenous to Sri Lanka. Netherlands Journal of Zoology, 34, 459-181.

Sheldon, A. L. (1968), Species diversity and longitudinal succession in stream fishes. Ecology, 49, 193-198.

Smogor, R. A. and Angermeier, P. L. (1999), Effects of drainage basin and anthropogenic disturbance on relations between stream size and IBI metrics in Virginia. In: Thomas P. Simon, editor. Assessment Approaches for Estimating Biological Integrity using Fish Assemblages. Lewis Press, Boca Raton, FL, USA. pp. 249-272.

Sydenham, D. H. J. (1977), The qualitative composition and longitudinal zonation of the fish fauna of the river Ogun. Rev. Zool. Afr., 91, 974-996.

Taylor, C. M. (1996), Abundance and distribution within a guild of benthic stream fishes: local processes and regional patterns. Freshwater Biology, 36, 385-396. 
Taylor, C. M.; Winston, M. R and Matthews, W. J. (1993), Fish species-environment and abundance relationships in a Great Plain river system. Ecography, 16, 16-23.

Tejerina-Garro, F. L. (2001), Étude des relations habitat-poissons dans les eaux courantes de Guyane Française pour l'évaluation de la qualité du milieu aquatique. $\mathrm{PhD}$ Thesis, University of Montpellier II, France, 243 pp.

Tito de Morais, L. and Lauzanne, L. (1994), Zonation longitudinale des peuplements ichtyques avant mise en eau de la retenue de Petit-Saut (Guyane française). Rev. Hydrobiol. Trop., 27 : (4), 467-483.

Tito de Morais, L.; Lointier, M. and Hoff, M. (1995), Extent and role for fish populations of riverine ecotones along the Sinnamary River (French Guiana). Hydrobiologia, 303, 163-179.

Vannote, R. L.; Minshall, G. W.; Cummins, K. W.; Seddel, J. R and Cushing, C. E. (1980), The river continuum concept. Canadian Journal of Fisheries and Aquatic Sciences, 37, 130-137.

Verneaux, J. (1977), Biotypologie de l'écosytème "eau courante". Détermination approchée de l'appartenance typologique d'un peuplement ichtyologique. Compte Rendu de l'Académie des Sciences (Paris), 284, 675-678.

Waite, I. R. and Carpenter, K. D. (2000), Associations among fish assemblage structure and environmental variables in Willamette Basin streams, Oregon. Transaction of the American Fisheries Society, 129, 754-770.

Werner, E. E. (1984), The mechanisms of species interactions and community organization in fish. In: Strong Jr., D. R.; Simberloff, D.; Abele, L. G. and Thistle, A. B. (Eds.). Ecological communities. Princeton University Press, Princeton, N.J. USA. pp. 360-382.
Whittier, T. R.; Hughes, R. M. and Larsen, D. P. (1988), The correspondence between ecoregions and spatial patterns in stream ecosystems in Oregon. Canadian Journal of Fisheries and Aquatic Sciences, 45, 1264-1278.

Wikramanayake, E. D. and Moyle, P. B. (1989), Ecological structure of tropical fish assemblages in wet-zone streams of Sri Lanka. Journal of Zoology (London), 218, 503-526.

Winemiller, K. O. and Leslie, M. A. (1992), Fish assemblages across a complex, tropical freshwater/marine ecotone. Environmental Biology of Fishes, 34, 29-50.

Winemiller, K. O. (1983), An introduction to the freshwater fish communities of Corcovado National Park, Costa Rica. Brenesia, 21, 47-66.

Zaret, T. M. and Rand, A. S. (1971), Competition in tropical stream fishes: support for the competitive exclusion principle. Ecology, 52, 336-342.

Received: July 15, 2003; Revised: December 02, 2003; Accepted: May 25, 2004. 